\title{
Fertility sparing strategies for pre- and peripubertal male cancer patients
}

\author{
Jan-Bernd Stukenborg ${ }^{1}$ and Christine Wyns $^{2}$ \\ ${ }^{1}$ NORDFERTIL Research Lab Stockholm, Childhood Cancer Research Unit, Department of Women's and Children's Health, Karolinska Institutet and \\ Karolinska University Hospital, Solna, Sweden \\ ${ }^{2}$ Cliniques Universitaires Saint-Luc, Université Catholique de Louvain, Brussels, Belgium
}

\begin{abstract}
Genetic parenthood following cancer therapy is considered to be a major factor of quality of life. Given the rising proportion of patients surviving cancer due to improved therapeutic protocols, it is an issue of growing importance. Hence, the efforts to preserve fertility have motivated researchers to develop options for the paediatric population facing fertility-threatening cancer therapies. In prepubertal boys who do not yet produce sperm, cryo-banking of testicular tissue containing spermatogonial stem cells (SSCs) is the only viable option for future fertility preservation. While proposed in a number of clinics worldwide, however, this strategy remains still experimental.

Transplanting the SSCs, or testicular tissue containing SSCs, back to the cured patient appears the most promising strategy. However, experiments performed with human testicular tissue in mice models reveal spermatogonial loss after transplantation, indicating the need for further optimisation of the transplantation procedure. The approach further poses the risk of reintroducing tumour cells back to the patient. In cases of haematological and blood-metastasising malignancies, in vitro generation of sperm combined with assisted reproductive technologies (ART), is the only possibility, avoiding reintroducing cancer cells. Although xenotransplantation would allow to recover sperm cells for ART being thus on the safe side with regard to cancer cells, the risk of infections with xeno-microbiological agents makes this option incompatible with clinical application. So far, offspring from in vitro matured sperm has only been achieved in mice. While human haploid germ cells, showing specific morphological features, expression of post-meiotic markers, as well as DNA and chromosome content, as well as fertilisation and development capacity, have been obtained by culturing spermatogonia or immature testicular tissue, the functionality of these cells still needs to be demonstrated. Despite the promising results obtained in recent years, further research is urgently warranted to establish a clinical tool offering these boys a fertility restoration option in the future. This minireview will focus on current achievements and future challenges of fertility preservation in young boys and underscore the next steps required to translate experimental strategies into clinical practice.
\end{abstract}

Keywords: testis, childhood cancer, infertility, fertility preservation, late effects, germ cells
Correspondence to: Jan-Bernd Stukenborg and Christine Wyns

Email: jan-bernd.stukenborg@ki.se and christine.wyns@uclouvain.be

ecancer 2020, 14:1016

https://doi.org/10.3332/ecancer.2020.1016

Published: $27 / 02 / 2020$

Received: 03/10/2019

Publication costs for this article were supported by ecancer (UK Charity number 1176307).

Copyright: (C) the authors; licensee ecancermedicalscience. This is an Open Access article distributed under the terms of the Creative Commons Attribution License (http:// creativecommons.org/licenses/by/3.0), which permits unrestricted use, distribution, and reproduction in any medium, provided the original work is properly cited. 


\section{Introduction}

Continuous efforts to improve oncological therapies have led to disease survival rates of more than 80\% in the paediatric population [1-4]. A well-known side effect of cancer treatment is infertility in adulthood which is now a major concern for patients and their parents. However, the availability of comprehensive information on fertility preservation options prior to cancer therapies results in up to $74 \%$ acceptance rates for fertility preservation procedures [5]. To date, none of the strategies to reduce the gonadotoxicity of cancer treatments have proven successful in male patients [6]. In prepubertal boys, for whom spermatogenesis has not yet started, the conventional approach of sperm cryopreservation for fertility preservation is not an option as the testis only contains diploid germ cells, including the spermatogonial stem cells (SSCs). SSCs are established in the human testis during the first months after birth, when gonocytes migrate and attach to the basement membrane of the seminiferous cords. They are the starting point for continuous sperm production, they are present in the testis during the whole life, unless there is a congenital abnormality with germ cell aplasia or they are lost due to a disease or other event (e.g., medical treatment) [7]. As SSCs can only be identified based on their functionality, i.e., auto renewal and differentiation capacities, proxy markers for the spermatogonial population were used to evaluate their presence in the testicular tissue. Studies that analysed the presence of spermatogonia in prepubertal testicular tissue from patient that underwent a fertility preservation procedure showed that spermatogonia were present in $96 \%$ to $100 \%$ of samples [8, 9]. Hence, cryopreservation of testicular tissue samples-containing SSCs-has been proposed as the sole method to potentially preserve fertility. With regard to peripubertal boys, 20\% in Tanner stage II of puberty already produce sperm [10]; therefore, cryopreservation of ejaculated semen from 12 years onwards or retrieval of testicular spermatozoa for those unable to provide a semen sample remains the priority. However, when no mature spermatozoa are collected, preserving the SSC via testicular tissue cryopreservation should also be considered for these patients.

\section{Prepubertal testicular tissue cryopreservation}

Protocols to preserve human prepubertal testicular tissue allowing for survival and proliferation of SSCs as well as reinitiation of spermatogenesis have been reported for more than a decade [11-14]. So far, the superiority of one cryopreservation procedure over the other has not been demonstrated. Cryopreservation of immature testicular tissue is now proposed in a growing number of clinics. National and international networks have been established in Europe and the USA to enhance access and allow sample routing to facilities that meet the local regulations on human tissue and cell banking [7, 15, 16]. Reported complication rates due to the biopsy procedures are low [17].

At present, current recommendations for the procedure include: (i) performing the procedure within a multi-collaborative care pathway with trained care providers available to discuss the risk-benefit balance, (ii) taking the testicular sample before starting chemo- and or radiotherapy treatment (if possible), thereby ensuring the storage of SSCs with the best possible DNA integrity and (iii) to combine the procedure, whenever possible, with another procedure requiring anaesthesia and to restrict the sampling to one testis.

\section{Perspectives and challenges of fertility restoration strategies}

As it stands, current investigations into the restoration of fertility using cryopreserved prepubertal testicular cells or tissue include in vivo approaches, such as autotransplantation of SSCs or immature testicular tissue, as well as in vitro development of mature sperm from SSCs. Here, we will briefly review the most recent achievements and challenges to be overcome before clinical implementation of the different strategies.

Autotransplantation of cryo-stored SSCs or immature testicular tissue can only be considered if there is no risk of cancer cell contamination of the testes. With regards to cell transplantation, attempts have been made to eliminate cancer cells from the testicular cell suspension through cell sorting techniques (for review see [18]) although further improvements and more powerful detection methods are required. Cell culture has also appeared useful to eliminate leukemic cells that were added to the testicular cell suspension although this study model may not be representative of cancer cell behaviour in tissues [19]. Transplantation of SSCs in seminiferous tubules was first described by Brinster and Avarbock in mice [20]. Generation of offspring in a number of other animal species has also been reported (for review, see [21]) with sperm obtained from transplanted SSCs in non-human primates resulting in viable embryos [22]. With the perspective of translating the 
technique to humans, methods to perform transplantation of cell suspensions in larger testes were evaluated. From these studies, ultrasound guided injection in the rete testis proved the most appropriate for human application [23]. In vitro propagation of SSCs will most likely be required before transplantation due to the scarcity of SSCs in the testis. Treatment related decrease of spermatogonia quantity reported in cancer patients [24, 25] as well as the poor colonisation efficiency of cell transplantation calculated in animal models [26, 27], also need to be taken in consideration. However, while in vitro propagation of human prepubertal SSCs was reported [28], safety issues linked to potential cell modification in culture as well as the functional proof that these cells are able to reinitiate sperm production, still need to be addressed.

Successful transplantation of freeze-thawed murine testicular tissue with birth of offspring was first described in 2002 [29], with subsequent reports in a number of other species (for review see [21]). Very recently, an important milestone was reached with the generation of offspring from transplanted immature testicular tissue in macaques [30]. Although yet to be translated to the clinic, it appears a likely frontrunner as the first fertility restoration option to enter pilot clinical trials. The procedure will however be restricted to patients with no risk of cancer recurrence, i.e., no possibility of neoplastic cells in the transplanted tissue \{i.e., non-malignant conditions, e.g., haematological diseases requiring conditioning chemotherapy before bone marrow transplantation, such as sickle cell disease, thalassemia major or severe immune diseases non-responsive to immunotherapy (for review see [31])\}. With regard to oncological patients, those with non-metastasising solid tumours could also come into consideration after tissue examination to exclude the presence of cancer cells in the tissue to be transplanted (providing that reliable techniques become available) and after fully informed patient-doctor decision and consent process. Currently, research is still ongoing to optimise tissue transplantation outcome as xenotransplantation experiments with human immature testicular tissue demonstrate a significant loss of spermatogonia, most likely due to hypoxia related to the absence of a vascular anastomosis between graft and host [18, 32, 33].

Options to restore fertility in patients with haematological or blood metastasising diseases are limited to strategies enabling the generation of sperm in vitro that may be used to fertilise eggs with intracytoplasmic sperm injection (for review see [34]).

The first studies demonstrating the potential of in vitro generated sperm to restore fertility were reported in the late 1990s when primary spermatocytes obtained from azoospermic patients were differentiated into haploid cells resulting in the birth of healthy infants after round spermatid injection in oocytes (ROSI) [35]. Other research groups revealed similar germ cell development using Vero cells to support the differentiation of spermatocytes in vitro [36]. More recently, in vitro generation of human haploid spermatids, able to develop into embryos after ROSI in murine oocytes, were obtained from SSCs of adult patients with cryptorchidism [37] and obstructive azoospermia [38].

The combination of functional somatic cells in direct contact with germ cells and the presence of a SSC microenvironment resembling the 3D-organisation of the seminiferous epithelium in situ have been highlighted as important factors to ensure survival and differentiation of male germ cells cultured in vitro (for review see [39]).

Hence, explant tissue or organotypic culture that maintains such 3D-organised microenvironment seems to be the most promising approach based on successful differentiation of murine SSCs into functional sperm in vitro [40] and the generation of human haploid germ cells from testicular tissue samples of cancer patients between 2 and 12 years of age [41, 42]. However, none of the reported studies demonstrated a system robust enough to differentiate human SSCs into functional sperm so far. Further research should focus on increasing knowledge on in vivo spermatogenesis to establish novel in vitro systems able to offer a safe, efficacious and efficient fertility preservation option for prepubertal cancer patients at risk of infertility.

\section{Conclusion}

Today, testicular cell or tissue cryopreservation is the only option available for young patients unable to produce sperm, to preserve fertility with the hope of future parenthood. While cryopreservation protocols are available to preserve human testicular cells and tissue, techniques aimed at obtaining mature sperm from cryopreserved immature testicular tissue are still in development. Although encouraging results have been obtained, either in vitro or in animal models, such techniques are not currently appropriate for clinical practice. Therefore, cryopreservation programs should be performed within settings which allow for proper follow-up of patients in the event of reassessment of current practice. In addition, research on fertility restoration strategies should be performed, if possible, within multi-centre studies, to ensure highquality research via standardised protocols. Health professionals, patients and their families should be informed about risks of treatments and the experimental nature of fertility preservation in prepubertal boys but also about research projects related to the field. 


\section{Acknowledgments}

The authors are grateful to Dr Elizabeth Oliver for English editing.

\section{Conflicts of interest}

The authors declare that they have no conflict of interest.

\section{Funding}

J.B.S acknowledges support from the Swedish Childhood Cancer Foundation (TJ2016-0093) and Swedish Research Council (2018-03094). C.W acknowledges support from the Fondation contre le cancer (FDC 2016-141), Fondation Salus Sanguinis and Fond National de la recherche scientifique de Belgique (Grants Télévie 7.4.572.09.F, 7.4616.11.F, 7.4596.13, 7.4554.14, 7.6511.16) for the experimental studies cited within this review.

\section{Authors' contributions}

Jan-Bernd Stukenborg and Christine Wyns contributed equally to this work.

\section{References}

1. Gatta G, Botta L, and Rossi S, et al (2014) Childhood cancer survival in Europe 1999-2007: results of EUROCARE-5--a populationbased study Lancet Oncol 15(1) 35-47 https://doi.org/10.1016/S1470-2045(13)70548-5

2. Smith MA, Altekruse SF, and Adamson PC, et al (2014) Declining childhood and adolescent cancer mortality Cancer 120(16) 2497-2506 https://doi.org/10.1002/cncr.28748 PMID: 24853691 PMCID: 4136455

3. Anderson C, Smitherman AB, and Nichols HB (2018) Conditional relative survival among long-term survivors of adolescent and young adult cancers Cancer 124(14) 3037-3043 https://doi.org/10.1002/cncr.31529 PMID: 29742278 PMCID: 6033635

4. Howlader NNA, Krapcho M, and Miller D, et al (eds) (2019) SEER Cancer Statistics Review, 1975-2016 (Bethesda, MD: National Cancer Institute) [https://seer.cancer.gov/csr/1975_2016/] based on November 8 SEER data submission, posted to the SEER web site

5. Wyns C, Collienne C, and Shenfield F, et al (2015) Fertility preservation in the male pediatric population: factors influencing the decision of parents and children Hum Reprod 30(9) 2022-2030 https://doi.org/10.1093/humrep/dev161 PMID: 26141713

6. Ntemou E, Alexandri C, and Lybaert P, et al (2019) Oncofertility: pharmacological protection and immature testicular tissue (ITT)based strategies for prepubertal and adolescent male cancer patients Int J Mol Sci 20(20) https://doi.org/10.3390/ijms20205223 PMID: 31640294 PMCID: 6834329

7. Stukenborg JB, Jahnukainen K, and Hutka M, et al (2018) Cancer treatment in childhood and testicular function: the importance of the somatic environment Endocr Connect 7(2) R69-R87 https://doi.org/10.1530/EC-17-0382 PMID: 29351905 PMCID: 5817964

8. Wyns C, Curaba M, and Petit S, et al (2011) Management of fertility preservation in prepubertal patients: 5 years' experience at the Catholic University of Louvain Hum Reprod 26(4) 737-747 https://doi.org/10.1093/humrep/deq387 PMID: 21227939

9. Wyns $C$ and de Michele E (2018) Fertility preservation in prepubertal boys: follow-up data after 13 years of clinical experience Fertil Steril 110(4) E87 https://doi.org/10.1016/j.fertnstert.2018.07.261 
10. Schaefer F, Marr J, and Seidel C, et al (1990) Assessment of gonadal maturation by evaluation of spermaturia Arch Dis Child 65(11) 1205-1207 https://doi.org/10.1136/adc.65.11.1205 PMID: 2248529 PMCID: 1792602

11. Keros V, Hultenby $\mathrm{K}$, and Borgstrom B, et al (2007) Methods of cryopreservation of testicular tissue with viable spermatogonia in pre-pubertal boys undergoing gonadotoxic cancer treatment Hum Reprod 22(5) 1384-1395 https://doi.org/10.1093/humrep/del508 PMID: 17259225

12. Kvist K, Thorup J, and Byskov AG, et al (2006) Cryopreservation of intact testicular tissue from boys with cryptorchidism Hum Reprod 21(2) 484-491 https://doi.org/10.1093/humrep/dei331

13. Wyns C, Curaba M, and Martinez-Madrid B, et al (2007) Spermatogonial survival after cryopreservation and short-term orthotopic immature human cryptorchid testicular tissue grafting to immunodeficient mice Hum Reprod 22(6) 1603-1611 https://doi.org/10.1093/ humrep/dem062 PMID: 17483089

14. Wyns C, Van Langendonckt A, and Wese FX, et al (2008) Long-term spermatogonial survival in cryopreserved and xenografted immature human testicular tissue Hum Reprod 23(11) 2402-2414 https://doi.org/10.1093/humrep/den272 PMID: 18664476

15. Picton HM, Wyns C, and Anderson RA, et al (2015) A European perspective on testicular tissue cryopreservation for fertility preservation in prepubertal and adolescent boys Hum Reprod 30(11) 2463-2475 https://doi.org/10.1093/humrep/dev190 PMID: 26358785

16. Valli-Pulaski H, Peters KA, and Gassei K, et al (2019) Testicular tissue cryopreservation: 8 years of experience from a coordinated network of academic centers Hum Reprod 34(6) 966-977 https://doi.org/10.1093/humrep/dez043 PMID: 31111889 PMCID: 6554046

17. Uijldert M, Meissner A, and de Melker AA, et al (2017) Development of the testis in pre-pubertal boys with cancer after biopsy for fertility preservation Hum Reprod 32(12) 2366-2372 https://doi.org/10.1093/humrep/dex306 PMID: 29040511

18. Del Vento F, Vermeulen M, and de Michele F, et al (2018) Tissue engineering to improve immature testicular tissue and cell transplantation outcomes: one step closer to fertility restoration for prepubertal boys exposed to gonadotoxic treatments Int J Mol Sci 19(1) https://doi.org/10.3390/ijms19010286 PMID: 29346308 PMCID: 5796232

19. Sadri-Ardekani H, Homburg CH, and van Capel TM, et al (2014) Eliminating acute lymphoblastic leukemia cells from human testicular cell cultures: a pilot study Fertil Steril 101(4) 1072-1078.e1 https://doi.org/10.1016/j.fertnstert.2014.01.014 PMID: 24581582

20. Brinster RL and Avarbock MR (1994) Germline transmission of donor haplotype following spermatogonial transplantation Proc Natl Acad Sci USA 91(24) 11303-11307 https://doi.org/10.1073/pnas.91.24.11303 PMID: 7972054 PMCID: 45219

21. Giudice MG, de Michele F, and Poels J, et al (2017) Update on fertility restoration from prepubertal spermatogonial stem cells: how far are we from clinical practice? Stem Cell Res 21 171-177 https://doi.org/10.1016/j.scr.2017.01.009 PMID: 28174013

22. Hermann BP, Sukhwani M, and Winkler F, et al (2012) Spermatogonial stem cell transplantation into rhesus testes regenerates spermatogenesis producing functional sperm Cell Stem Cell 11(5) 715-726 https://doi.org/10.1016/j.stem.2012.07.017 PMID: 23122294 PMCID: 3580057

23. Schlatt S, Rosiepen G, and Weinbauer GF, et al (1999) Germ cell transfer into rat, bovine, monkey and human testes Hum Reprod 14(1) 144-150 https://doi.org/10.1093/humrep/14.1.144 PMID: 10374111

24. Stukenborg JB, Alves-Lopes JP, and Kurek M, et al (2018) Spermatogonial quantity in human prepubertal testicular tissue collected for fertility preservation prior to potentially sterilizing therapy Hum Reprod 33(9) 1677-1683 https://doi.org/10.1093/humrep/dey240 PMID: 30052981 PMCID: 6112575

25. Poganitsch-Korhonen M, Masliukaite I, and Nurmio M, et al (2017) Decreased spermatogonial quantity in prepubertal boys with leukaemia treated with alkylating agents Leukemia 31(6) 1460-1463 https://doi.org/10.1038/leu.2017.76 PMID: 28270690 PMCID: 5467043 
26. Dobrinski I, Avarbock MR, and Brinster RL (1999) Transplantation of germ cells from rabbits and dogs into mouse testes Biol Reprod 61(5) 1331-1339 https://doi.org/10.1095/biolreprod61.5.1331 PMID: 10529282

27. Dobrinski I, Ogawa T, and Avarbock MR, et al (1999) Computer assisted image analysis to assess colonization of recipient seminiferous tubules by spermatogonial stem cells from transgenic donor mice Mol Reprod Dev 53(2) 142-148 PMID: 10331452

28. Sadri-Ardekani H, Akhondi MA, and van der Veen F, et al (2011) In vitro propagation of human prepubertal spermatogonial stem cells JAMA 305(23) 2416-2418 https://doi.org/10.1001/jama.2011.791 PMID: 21673293

29. Shinohara T, Inoue K, and Ogonuki N, et al (2002) Birth of offspring following transplantation of cryopreserved immature testicular pieces and in-vitro microinsemination Hum Reprod 17(12) 3039-3045 https://doi.org/10.1093/humrep/17.12.3039 PMID: 12456600

30. Fayomi AP, Peters K, and Sukhwani M, et al (2019) Eliminating acute lymphoblastic leukemia cells from human testicular cell cultures: a pilot study Science 363(6433) 1314-1319 https://doi.org/10.1126/science.aav2914 PMID: 30898927 PMCID: 6598202

31. Wyns C, Curaba M, and Vanabelle B, et al (2010) Options for fertility preservation in prepubertal boys Hum Reprod Update 16(3) 312-328 https://doi.org/10.1093/humupd/dmp054 PMID: 20047952

32. Poels J, Van Langendonckt A, and Many MC, et al (2013) Vitrification preserves proliferation capacity in human spermatogonia Hum Reprod 28(3) 578-589 https://doi.org/10.1093/humrep/des455 PMID: 23315062

33. Poels J, Abou-Ghannam G, and Decamps A, et al (2016) Transplantation of testicular tissue in alginate hydrogel loaded with VEGF nanoparticles improves spermatogonial recovery J Control Release 234 79-89 https://doi.org/10.1016/j.jconrel.2016.05.037 PMID: 27189137

34. Oliver E and Stukenborg JB (2019) Rebuilding the human testis in vitro Andrology https://doi.org/10.1111/andr.12710 PMID: 31539453

35. Tesarik J, Bahceci M, and Ozcan C, et al (1999) Restoration of fertility by in-vitro spermatogenesis Lancet 353(9152) 555-556 https://doi.org/10.1016/S0140-6736(98)04784-9 PMID: 10028987

36. Tanaka A, Nagayoshi M, and Awata S, et al (2003) Completion of meiosis in human primary spermatocytes through in vitro coculture with Vero cells Fertil Steril 79(Suppl 1) 795-801 https://doi.org/10.1016/S0015-0282(02)04833-1 PMID: 12620493

37. Yang S, Ping P, and Ma M, et al (2014) Generation of haploid spermatids with fertilization and development capacity from human spermatogonial stem cells of cryptorchid patients Stem Cell Rep 3(4) 663-675 https://doi.org/10.1016/j.stemcr.2014.08.004

38. Sun M, Yuan Q, and Niu M, et al (2018) Efficient generation of functional haploid spermatids from human germline stem cells by three-dimensional-induced system Cell Death Differ 25(4) 749-766 https://doi.org/10.1038/s41418-017-0015-1 PMID: 29305586 PMCID: 5864226

39. Alves-Lopes JP and Stukenborg JB (2018) Testicular organoids: a new model to study the testicular microenvironment in vitro? Hum Reprod Update 24(2) 176-191 https://doi.org/10.1093/humupd/dmx036

40. Sato T, Katagiri K, and Gohbara A, et al (2011) In vitro production of functional sperm in cultured neonatal mouse testes Nature 471(7339) 504-507 https://doi.org/10.1038/nature09850 PMID: 21430778

41. de Michele F, Poels J, and Weerens L, et al (2017) Preserved seminiferous tubule integrity with spermatogonial survival and induction of Sertoli and Leydig cell maturation after long-term organotypic culture of prepubertal human testicular tissue Hum Reprod 32(1) 32-45

42. de Michele F, Poels J, and Vermeulen M, et al (2018) Haploid germ cells generated in organotypic culture of testicular tissue from prepubertal boys Front Physiol 91413 https://doi.org/10.3389/fphys.2018.01413 PMID: 30356879 PMCID: 6190924 